\title{
ALLOY 625 WELD OVERLAYS FOR OFFSHORE AND ONSHORE PROJECTS
}

\author{
Dan Capitanescu, Welding Specialist \\ Capitan Welding Technologies Inc. \\ 9304 Horton Road S.W. \\ Calgary, Alberta \\ T2V $2 \times 4$ \\ Canada
}

\begin{abstract}
This technical report presents the most complete and in-depth design, research and Eabrication of Alloy 625 weld overlayed carbon steel pipe and fittings such as: 90 degree and 45 degree LR Elbows, Tees, Dished Heads, Reducers, Weld Neck Flanges, Valves, Spools, Manifolds, Nozzles, Blinds and so forth. Major developments for offshore projects took place in Calgary, Canada during 1989, 1990 and continued through 1991 such as:

- Development of an entire range of Alloy 625 weld overlay and butt welding procedures to cover majority of the welding processes: SAW, Pulsed GMAW, SMAW, GTAW, FCAW and base materials such as: P1 and 4130 with thicknesses from $.250 \mathrm{in}$. $(6.3 \mathrm{~mm})$ to no 1 imit to be weld overlayed or butt welded.

- Development of a wide range of welding procedures to join dissimilar and similar materials such as: P1 to P1, P43 to P43, P1 to P45, P43 to P45, 4130 to 4130,4130 to 443 etc. All using the same filler metal: Alloy 625 .

- Development of special welding consumables with special formulation to be used on of fshore projects.

- Development of a unique welding technology and welding technique to provide a low iron content Alloy 625 weld deposit on carbon steel base material.

- Development of a specialized welding equipment to perform weld overlay on 45 degree and 90 degree LR Elbows with any exotic welding filler metal including Alloy 625 , employing a high productivity SAW system with near zero defect rate.

- Currusion tests performed on Alloy 625 weld overlay deposits and corrosion tests performed on self contained Alloy 625 weld over ayed Autoclaves.

- Complete study of Alloy 625 flux cored wire: weldability, corrosion testing and weld defect occurrence while weld deposits are performed using FCAW fillers available today.
\end{abstract}




\section{Introduction}

As the Farth's Oil and Gas Reserves diminish and the search for additional and deeper rcsources increases, there is a growing tendency towards offshore Developments as the answer to self-sufficiency or to at least reducing oil and Gas dependability on other oil producing countries. The search for and findings of $0 i 1$ and Gas at such great depths are marked with high pressures, high $\mathrm{H} 2 \mathrm{~S}$ and $\mathrm{CO} 2$ contents and very often elevated temperatures. Complicating the situation and making the project's engineer's life even more challenging is the issue of materials that were proven acceptable for such projects just a few years ago are now not good enough because of the increased pressures, $\mathrm{H} 2 \mathrm{~S}$ and $\mathrm{CO} 2$ concentrations and temperatures.

Just a few years ago an "Exotic Material" was a material used for a multitude of corrosion resistant applications. However, today for majority of the onshore and offshore 0il and Gas Developments "Exotic Material" has to be "Super Alloy".

Such major developments combining the drastic changes in the environment awareness and the ever increasing cost of maintenance and equipment repair has put the super Alloys in the spotlight and the Alloy 625 on the top of the list as one of the most flexible alloys to be used as a "Corrosion Barrier" for most applications. From an economical point of view Alloy 625 looks very unattractive to many potential users because of its very high price tag. As a direct result of the high price of Alloy 625 solid fittings, Alloy 625 weld overlayed pipe and fittings is a very obvious alternative with excellent technical results and remarkable cost reductions.

\section{Alloy 625 weld overlays: Welding Processes And Welding Technologies}

Choosing the right combination of welding process and welding technique for the proper application is what makes up for most of the secret of Alloy 625 weld overlays.

As shown in Table I, Alloy 625 displays such properties that will make welding anything but an easy task.

Table I

\begin{tabular}{|c|c|c|c|c|c|c|}
\hline \multicolumn{7}{|l|}{$\begin{array}{l}\text { Physical Constants and Thermal Properties } \\
\text { Density, } \mathrm{lb} / \mathrm{cu} \text { in. }\end{array}$} \\
\hline Modulus of Elasticity. psi & \multicolumn{6}{|c|}{ Specific Heat, Btu $/ \mathrm{lb} /{ }^{\circ} \mathrm{F}$} \\
\hline Tension & $70^{\circ} \mathrm{F}$ & & & & & 0.098 \\
\hline Torsion & Curie Tempera & ture, ${ }^{\circ} \mathrm{F}$ & & & & $<-320$ \\
\hline \multirow[t]{2}{*}{ Poisson's Ratio } & Permeability ( 7 & ${ }^{\circ} \mathrm{F}, \mathrm{H}=$ & $=2000$ & rsted) & .. & 1.0006 \\
\hline & $70^{\circ} \mathrm{F}$ & $200^{\circ} \mathrm{F}$ & $500^{\circ} \mathrm{F}$ & $1000^{\circ} \mathrm{F}$ & $1500^{\circ} \mathrm{F}$ & $2000^{\circ} \mathrm{F}$ \\
\hline \multirow{3}{*}{$\begin{array}{l}\text { Thermal Expansion, }{ }^{\mathrm{i}} \mathrm{in} . / \mathrm{in} . /{ }^{\circ} \mathrm{F} \times 10^{-\mathrm{o}} \\
\text { Thermal Conductivity, Btu/sq } \mathrm{ft} / \mathrm{hr} / \mathrm{in} .{ }^{\circ} \mathrm{F} \\
\text { Electrical Resistivity, ohm } / \mathrm{circ} \mathrm{mil} / \mathrm{ft}\end{array}$} & 5.5 & 7.1 & 7.4 & 7.8 & 8.7 & - \\
\hline & 68 & - & 93 & 121 & 151 & - \\
\hline & 776 & - & 809 & 830 & 821 & 806 \\
\hline
\end{tabular}


The bottom line is that Alloy 625 weld deposits will allow a good appearance and sound weld deposit only if the welding process used falls into the category of "Hot" processes such as: SAW, GTAW, PLASMA TRANSFER $A R C$, etc. On the other hand, with any "Hot" process high dilution comes as a normal attachment.

A smart compromise has to be found and an ideal balance of sound weld deposit - low dilution occurrence has to be found. One of the most successful candidates in achieving most of the advantages in weld overlaying with Alloy 625 is submerged, Arc Welding System. With a proper welding technique that is tailored differently to various base metal thicknesses and shapes the SAW process will definitely show the following positive aspects:

- High deposition rates.

- Near zero weld deposit defects.

- Almost perfect "Smooth" weld deposit appearance.

- Controllable dilution rates.

- Minimum filler metal waste.

- Very good consistency in weld overlay deposit chemistry.

- Equipment flexibility to produce weld overlays in a very small bore( 1 in. dia.) pipe and Eittings.

- Low cost of labour (machine operator versus skilled welder).

Vexy successful attempts were made to qualify Alloy 625 weld overlays on P1 and 4130 base materials. Table II is a summary of various overlay and butt welding procedures all having in common one thing: Alloy 625 filler metal.

Table II - Summary of All Mobile Bay Qualifications

\begin{tabular}{|c|c|c|c|c|c|c|c|}
\hline \multicolumn{2}{|c|}{$\begin{array}{l}\text { WELDING } \\
\text { Process }\end{array}$} & \multirow{2}{*}{$\begin{array}{c}\text { BASE METAL } \\
\text { P1 } 14130 \\
\end{array}$} & \multirow{2}{*}{$\begin{array}{l}\begin{array}{l}\text { THICKNESS } \\
\text { Qualified }\end{array} \\
\text {.250"to No max }\end{array}$} & \multicolumn{3}{|c|}{ CONSUMABLES } & \begin{tabular}{c|c|} 
One layer & Two layer \\
E/ER NiCrMo-3
\end{tabular} \\
\hline \multirow{4}{*}{$\frac{\omega}{\alpha}$} & & & & 625 & $\# 7$ & & \\
\hline & SAW & & $250^{\circ}$ to No max & 625 & $\not 77$ & & \\
\hline & \multirow{2}{*}{ GTAW } & & $250^{\circ}$ to No max & 625 & & $\mathrm{Ar}$ & \\
\hline & & & $250^{\prime \prime}$ to No max & 625 & & Ar & \\
\hline \multirow{2}{*}{$\mid$} & & & $250^{\prime \prime}$ to No max & 112 & & & \\
\hline & SMAW & & $250^{\circ}$ to No max & 112 & & & \\
\hline \multirow[b]{3}{*}{3} & Pulsed & & $250^{\prime \prime}$ to No max. & 625 & & $\mathrm{Ar}$ & \\
\hline & GMAW & & $250^{\prime}$ to No $\max$ & 625 & & Ar & \\
\hline & FCAW & & $250^{\circ}$ to No $\max$ & 625 & & Ar. $\infty$ & \\
\hline \multicolumn{2}{|c|}{$\begin{array}{l}\text { WELDING } \\
\text { Process }\end{array}$} & $\frac{\text { METAL }}{\mid \text { P45 } / 4130}$ & $\begin{array}{l}\text { THICKNESS } \\
\text { Qualified }\end{array}$ & $\frac{\mathrm{CO}}{\mathrm{Filler}}$ & $\frac{\overline{\text { VSUMA }}}{\text { |Electr }}$ & $\frac{\text { BBLES }}{\text {.GaS }}$ & Remarks \\
\hline \multirow{8}{*}{ 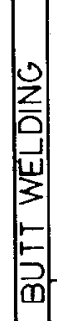 } & & & $.1875^{\prime \prime}-1.000^{\prime}$ & 625 & 112 & $A r$ & Overlay: ERNiCrMo.3 \\
\hline & \multirow{7}{*}{ 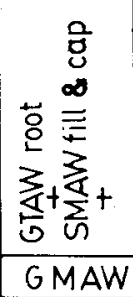 } & & $.1875^{\prime \prime}-1.436^{\prime}$ & 625 & 112 & Ar & Overlay(P1):ERNIC $-M O 3$ \\
\hline & & & $1875^{\prime \prime}-1.436^{\prime}$ & 625 & 112 & $\mathrm{Ar}$ & Overlay (PI):ERNiCrMo.3 \\
\hline & & & $.0625^{\prime \prime}-.674^{\prime}$ & 625 & 112 & Ar & \\
\hline & & & $.025^{\prime \prime}-.674$ & 625 & 112 & $\mathrm{Ar}$ & \\
\hline & & & $.0625^{\prime \prime}-.674^{\prime}$ & 625 & 112 & $\mathrm{Ar}$ & \\
\hline & & & $1875^{\prime \prime}-1.500^{\prime}$ & 625 & 112 & Ar & PWHT: $1100^{\circ} \mathrm{F}, \mathrm{HRC} \leqslant 22$ \\
\hline & & & $.1875^{*}-2.500$ & 625 & 1112 & Ar & Fill\&Cap Pulsed GMAW " \\
\hline
\end{tabular}


Very valuable data has been complled, some reinforcing former developments on Alloy 625 welding but most of the findings are new. An integral part of the welding technology developed are four factors that were found to be most influential in achieving the best end results: fillex metal diameter, welding position, welding speed and flux type (Eor saw).

Eiller Metal Diameter

It has been many years sirce different researchers have established the direct relationship between Alloy 625 cracking during welding and the weld puddle size and shape. Mathematical formulas will only eventual help to establish the stress forces that occur at the surface line of an Alloy 625 weld puddle. What these formulas will not provide is the practical means to avoid such occurrences. What is an ideal puddle shape that will allow after freezing a crack free weld? The size and shape of a weld pudale will be decided mainly by the wire diameter, welding speed and weld position.

With the SAW process used to perform about $90 \%$ of the Alloy 625 weld overlays on this development and an approximate 20,000 lbs of Alloy 625 (ERNiCrMo-3) filler metal being melted the one diameter that emerged as being the most sultable for SAW process was $1 / 16 "(1.6 \mathrm{~mm})$. A smaller diameter filler metal was used (approximately 400 lbs of Alloy 625, .045" $(1.2 \mathrm{~mm})$ ) and displayed poorer results then 1/16" diameter as far as weld deposit appearance and deposit defects are concerned. With the pulsed GMAW the only diameter with excellent results was .045" (12mm).

With the SMAw process after an approximate quantity of 2000 lbs of Alloy 625 welding rods were used the most successfully used diameters in achieving weld deposits free of defects were $1 / 8 " 3.2 \mathrm{~mm}$ ) and $5 / 32$ " $(4.0 \mathrm{~mm})$. On GTAW even though the quantities used were significantly lower than the ones used with SAW and SMAW we can conclude that one diameter provided defect free weld deposits : $1 / 8$ " (3.2mm).

In conclusion we can say the following:

- Smaller diameter Alloy 625 filler metals allow zero crack weld deposits.

- Small weld puddles are preferred to large ones in order to reduce stress cracking and bring the two expansion coefficients of the carbon steel base metal and Alloy 625 weld deposit to a common ground.

- In the case of SAW process feeding small filler metal diameters definitely help to maintain a continuous flow that directly helps in maintaining welding parameters (current and voltage) to a constant level which translate into a sound weld deposit.

- Pulsed GMAW has emerged as the process that will replace completely the slower, low productivity SMAW process.

Welding Position, Welding Speeds And Flux Type

Welding positions and welding speeds are very important factors in producing a sound Alloy 625 weld deposit. For SAw process Alloy 625 combined with a proper welding flux has the characteristic of "Fast Freeze" weld puddle which makes it a very good candidate for "out of position" welds with very good resulls for SAW welding near the " 3 o'clock" position. 
The negative side of that. is that in order to perform a SAW weld in a near "3 'clock" position the welding speed has to be somewhere near 18-25 IPM and this situation will lead to "Higher" than normal dilution rates. Very good quality SAW Alloy 625 weld overlays were achieved in near "3 o'clock" position especially in performing the weld overlays on 90 degree clbows. Figure 1 shows a schematic of such near "3 o'clock" SAW weld overlay on 90 degree elbows with several production chemistries performed on $10 \%$ of the elbows showing excellent results.

Figure 1 - "Out of Position" Elbow Overlay

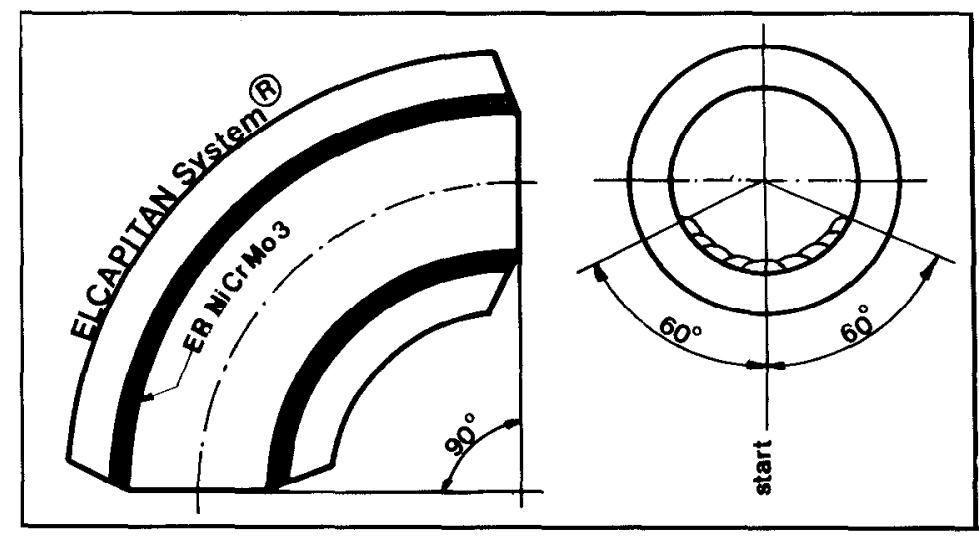

From a practical point of view SAW Alloy 625 weld overlays can be successfully achieved in "Out of Position" situations only on the condition that while the welding puddle solidifies it has the kind of support that will not let it "RUN AWAY" and be disturbed to any extent. A "RUN AWAY" puddle will create weld cracks through out the entire weld.

\section{Flux Type Used For SAW Overlays with Alloy 625}

The most valuable finding during this development was, without a doubt, the predominant influence of the type of flux used tor SAW overlay on carbon steel base material in regards to the occurrence of cracking in the weld deposit. As a normal practice and as a minimum mandatory test on weld overlayed deposits, the liquid penetrant test is the test that will decide if a corrosion resistant weld overlay will perform or not depending on the overlay's surface conditjon. "Defect free" weld overlay deposits will "read" in a similar manner as a $100 \%$ radiography test of a butt weld with no defects.

Duxing the development, after a sizable number of fittings were finalized and ready to be butt welded to the corresponding clad pipe, multiple cracks were detected in the weld overlay deposit during a radiographic test. The findings were very surprising due to the surface quality following liquid penetrant test. There were approximately 150 fittings (elbows, tees, flanges, blinds, reducers, caps, etc.) varying in sizes from 6" to 18" that after radiographic testing showed cracks varying in number from 4 to 20 on the same fitting and from 1/4" to 2" in length. 
A great amount of filler metal (approximate $5000 \mathrm{lbs}$ ) and flux (approximate 7000 lbs) were wasted. After a thorough technical investigation one element stood out in our findings: high amounts of silicon were found in the weld deposits. The cracks were very consistent from one point of view - all "embedded" in the weld deposit. There was not any finding to show a crack propagated either into the base material or to the weld overlay surface. A typical crack found in Alloy 625 weld deposit is shown in Fiqure 2 .

\section{Figure 2 - Alloy 625 Cracking Due To High Silicon Content of SAw Flux}

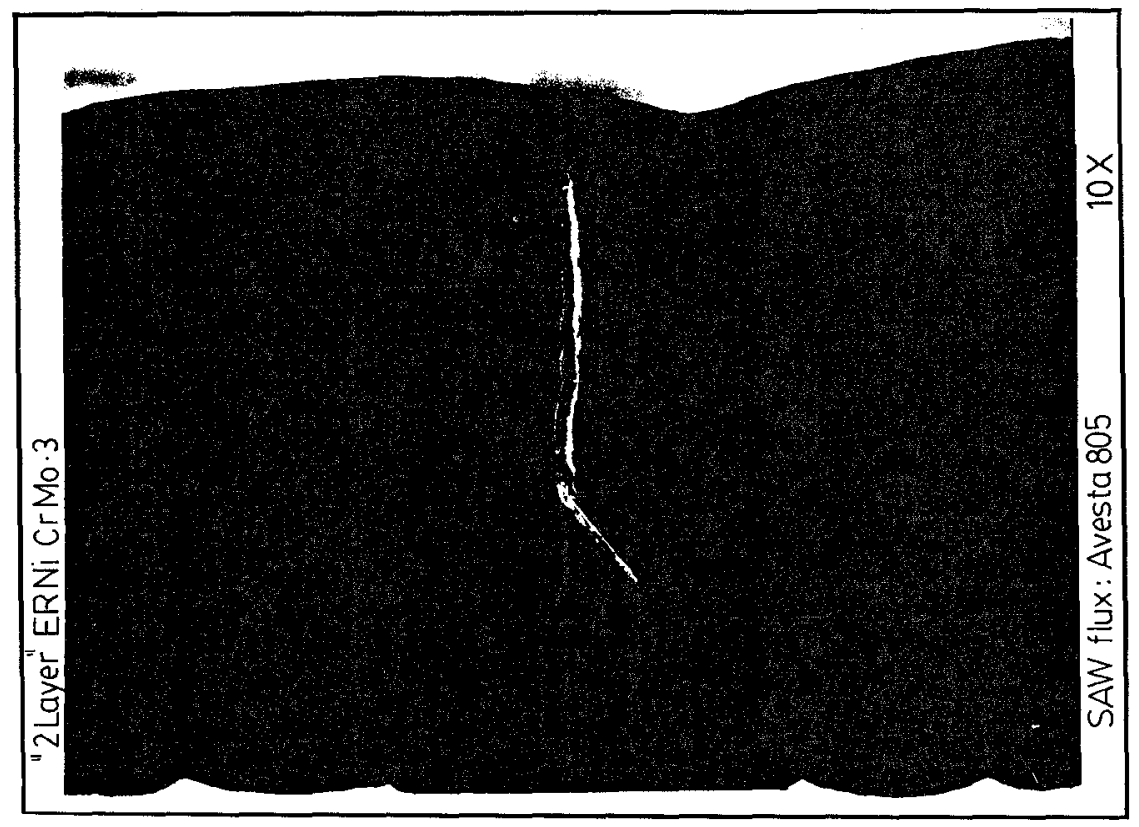

As has been previously established in the welding community, solidification cracking occurs when the solidifying weld pool is subjected to transverse shrinkage. Very often, in the centerline of the weld which solidifies last, there is an important amount of low melting point impurities. Due to this occurrence, the weld loses a good portion of its ductility. High strain in conjunction with low ductility leads to cracking in the weld. The occuryence of such cracks very often takes place in alloys $\mathrm{rich}$ in low melting points or low ductile elements such as silicon combinations. As mentioned above during a very thorough lab test investigation significant amounts of silicon were found around the crack as can be seen in Figure 3 . 
Figure 3 - The "ANATOMY" of Alloy 625 Crack

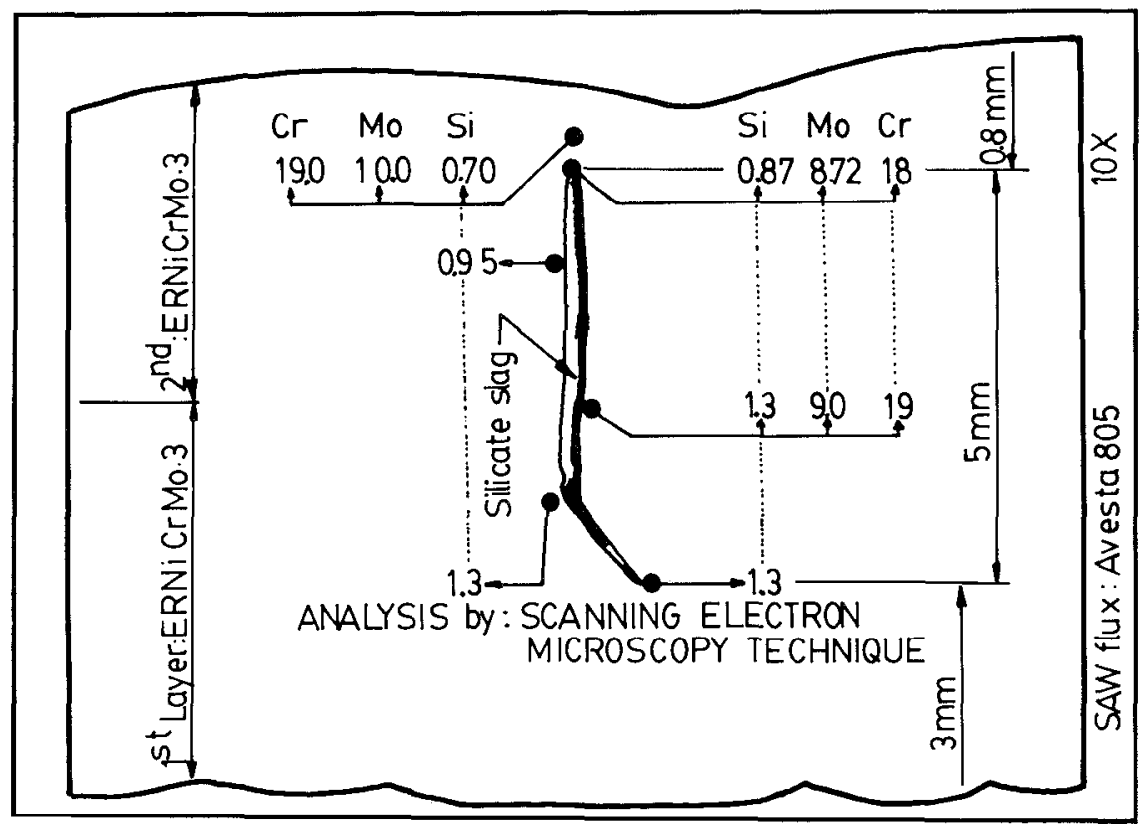

It is known that SAW weld overlay deposits with Alloy 625 is anything but an easy job due to the very high nickel content of the filler. An easy way out from having SAW weld overlay deposits with rough appearances is to use a silicon rich flux which will automatically ensure a very "fluid" slag in combination with "silent" arc and no occurrence of heavy slag or slag "bubbling" effect. This was the case of Flux \#805 which produced very good appearance weld deposits but full with "under surface" cracks. Immediate steps were taken and new welding procedures were developed using a silicon free flux. The new flux, Flux \#7, is very difficult to weld with due lo very poor flow characteristics in mollen state; but there followed an approximate 10,000 lbs of Alloy 625 weld deposits with FRNiCrMo-3 filler and Flux $\# 7$ with not one single occurrence of cracks.

\section{Low Iron A110y 625}

The subject of producing a low iron Alloy 625 weld deposit occurred at the very first stage of development. Extensive corrosion tests were conducted by various parties interested in Mobile Bay Development and for that environmert soljd Alloy 825 was found appropriate to successfully withstiand the corrosion produced by known H?S - COZ concentrations. Table II shows a typical chemistry of Alloy 825. 


\begin{tabular}{|c|c|}
\hline \multicolumn{2}{|l|}{ INCOLOY alloy 825} \\
\hline Nickel .............. & $38.0-46.0$ \\
\hline Carbon ................. & 0.05 max. \\
\hline Manganese ... & $1.0 \max$. \\
\hline Iron ….............. & Balance \\
\hline Sulfur .................... & 0.03 max. \\
\hline Silicon .......... & $0.5 \max$. \\
\hline Copper & $1.5-3.0$ \\
\hline Chromium & $19.5-23.5$ \\
\hline Aluminum & $0.2 \max$. \\
\hline $\begin{array}{l}\text { Titanium } \\
\text { Molybdenum }\end{array}$ & $\begin{array}{l}0.6-1.2 \\
2.5-3.5\end{array}$ \\
\hline & \\
\hline
\end{tabular}

During the course of this of this development due to great difficulty in procuring Alloy 825 fittings in time and at an acceptable price tag a decision was made that all fittings larger than $4^{\prime \prime}$ dia. to be weld overlayed with Alloy 625 in order to ensure a weld deposit with an acceptable iron level (to equal or better Alloy 825). Due to the quantity of fittings to be weld overlayed a total review of the project specifications took place in order to accommodate an "achievable" production weld overlay chemistry throughout the entire range of fittings of various diameters and shapes.

To ensure that the weld deposit chemistries limits were going to be achieved for production weld overlays further step was taken in producing "Special chemistry Low Iron" Alloy 625 filler metals. Table IV shows the special chemistries of the three types of filler metals used on the project.

During the course of the development a great deal of welding procedures were developed and an important number of chemical tests on Alloy 625 weld overlays were performed. Also during the development a $10 \%$ production weld overlays chemical tests were performed. The conclusion is that regardless of the welding process used a great chemistry consistency was achieved throughout the entire project and all the results were well within the project specifications - Table V.

In conclusion to the "Iron Content" subject we can say that in achieving the levels set through the projects specifications, and producing and using a low iron filler metal was most helpful and also proved economically feasible. This was due to weld overlaying that was performed in normal "Shop Production Conditions" on various items with a multitude of diameters, shapes and configurations as shown in Figure $4 a, b, c, d, e \& f$ without making use of any sophisticated welding technology or technique more appropriate for Research and Development or laboratory conditions. 
Table IV

\begin{tabular}{|c|c|c|c|c|c|c|c|c|c|c|c|c|c|c|}
\hline \multirow{2}{*}{$\begin{array}{l}\text { WELDING } \\
\text { PROCESS }\end{array}$} & \multirow{2}{*}{$\begin{array}{l}\text { FILLER } \\
\text { CLASS }\end{array}$} & \multirow{2}{*}{$\begin{array}{l}\text { FILLER TRADE } \\
\text { NAME }\end{array}$} & \multicolumn{4}{|c|}{$H E M \mid C A$} & \multicolumn{8}{|c|}{$A N A L Y S \mid S \%$} \\
\hline & & & C & $\mathrm{Cr}$ & $\mathrm{Ni}$ & $\mathrm{Mn}$ & $S$ & Mo & $\mathrm{Fe}$ & $\overline{T_{1}}$ & $\mathrm{Cu}$ & $\mathrm{NB}$ & & \\
\hline & ERN & $020 \mathrm{VI}$ & 13 & 222 & 4.0 & .02 & 0 & & & & & 5 & 0 & $1] 2$ \\
\hline & & & & 21 & 63.1 & .0 & .3 & & 1. & .20 & & 3.4 & & \\
\hline & & & & 2 & & .0 & 0 & & .7 & .20 & & 35 & 00 & 12 \\
\hline & ERNiCrMo.3 & 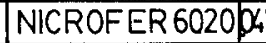 & 015 & 22 & 64.0 & 02 & .0 & 9.2 & 69 & .2 & .0 & 34 & 003 & 0.14 \\
\hline
\end{tabular}

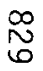

Table V

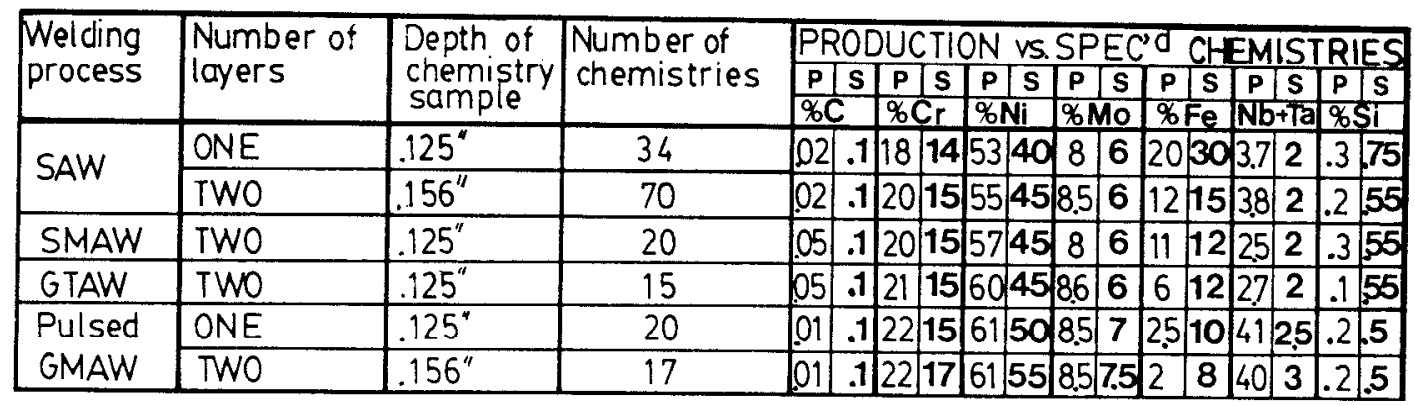



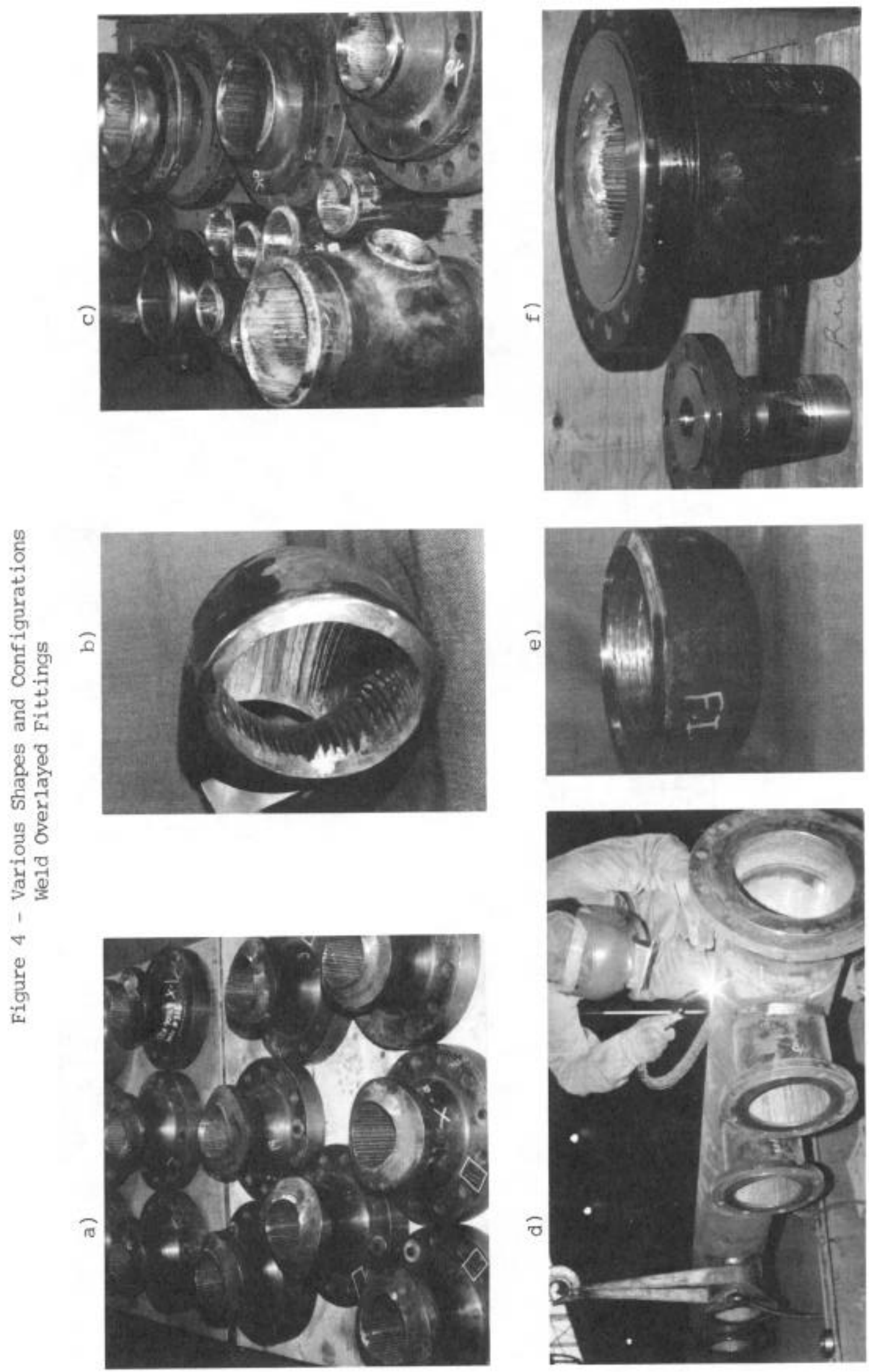
Even though corrosion tests on Alloy 825 proved it more than suitable for use on the environment occurring from Mobile Bay conditions, extensive corrosion tests were conducted on Alloy 625 weld overlay deposits performed on various items such as: P1 base material plates, 4130 base material plates, Pl base material fittings (tees, etc.) or whole self contained autoclaves with a multitude of weld overlayed items as can be seen in Table VT.

Table VI

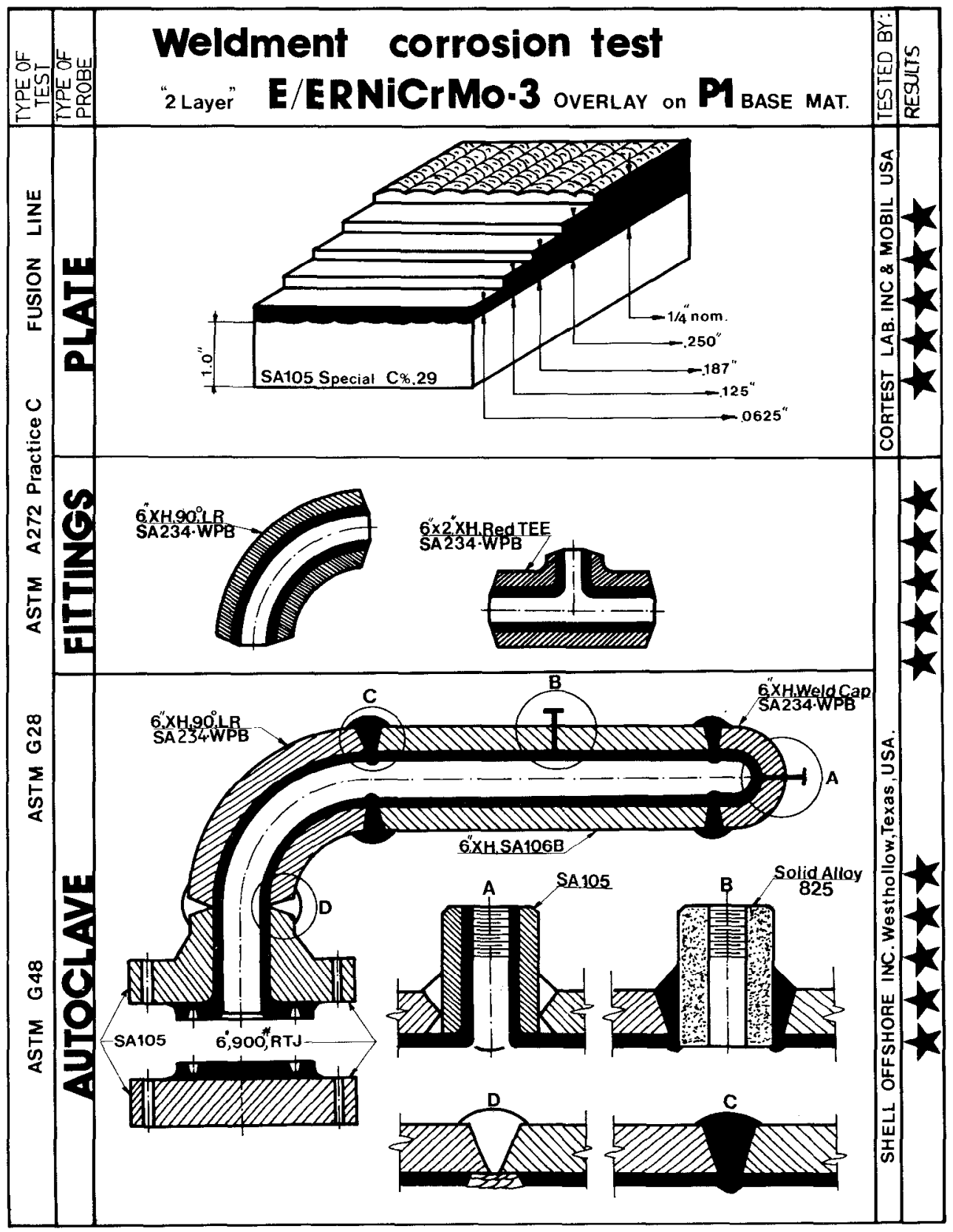


The tests were very elaborate and under severe conditions well surpassing

the production ones. Excellent results were somewhat expected. It was very reassuring to demonstrate what the actual point of the whole exercise was: that Alloy 625 weld overlay deposits on carbon steel base materials are at least as corrosion resistant as solid Alloy 825.

Specialized Equipment To Perform Alloy 625

Weld Overlays of Small Bore Pipe And Fittings

The idea of Alloy 625 weld overlaying on fittings with a large variety of shapes and diameters can be achieved only with highly specialized welding equipment. "Shape Welding" and "Shape Weld overlaying" are ideas many people were dealing with for quite some time but to bring it from theory to practice as has been demonstrated during this project it takes an entire firm to specialize only in such works.

Besides the normal range of different types of welding equipment to weld overlay flanges, tees, reducers etc. a major development took place during the course of this project: the development of a unique SAW Welding System to weld overlay 90 degree Long Radius Elbows with diameters starting as low as 6". As can bee seen in Table VII an entire range of fittings were weld overlayed as part of the Mobile Bay Development.

\section{Economical Aspects of Alloy 625 Weld Overlay}

The significant savings of using Alloy 625 weld overlayed pipe fittings versus solid Alloy 625 or 825 fittings made possible this project from the very beginning. Choosing Alloy 625 weld overlayed fittings over soljd centrifugally clad, hip clad etc. proved to be a very big economical success as well as having a technical advantages from the safety and corrosion resistant point of view. Figure 5 shows a clear picture of the above statement. For the accurateness of this statement a "One Diameter" range of fittings were chosen to be displayed. 


\begin{tabular}{|c|c|c|c|c|}
\hline WELD OVERLAYED COMPONENENT & Base Material & WeldProcess & NDE & Remarks \\
\hline $\begin{array}{l}\text { BLINDS } \\
\& \\
\text { FLANGES }\end{array}$ & $\begin{array}{l}\text { P1 } \\
\text { P4 } \\
4130\end{array}$ & $\begin{array}{l}\text { SAW } \\
\text { Pulsed GMAW } \\
\text { SMAW } \\
\text { GTAW }\end{array}$ & $\begin{array}{l}100 \% \mathrm{PT} \\
100 \% \mathrm{RT}\end{array}$ & RF \& RTJ \\
\hline & $\begin{array}{l}\text { P1 } \\
\text { P4 } \\
4130\end{array}$ & $\begin{array}{l}\text { SAW } \\
\text { Pulsed GMAW } \\
\text { GTAW }\end{array}$ & $\begin{array}{l}100 \% \mathrm{PT} \\
100 \% \mathrm{RT}\end{array}$ & $\begin{array}{l}\text { STRAIGHT \& } \\
\text { REDUCING }\end{array}$ \\
\hline ELBOWS & $\begin{array}{l}\text { P1 } \\
\text { P4 } \\
4130\end{array}$ & SAW & $\begin{array}{l}100 \% \mathrm{PT} \\
100 \% \mathrm{RT}\end{array}$ & $\begin{array}{l}90^{\circ} \& 45^{\circ} \\
04^{\prime \prime} \min .\end{array}$ \\
\hline & $\begin{array}{l}\text { P1 } \\
\text { P4 } \\
4130\end{array}$ & $\begin{array}{l}\text { SAW } \\
\text { Pulsed GMAW } \\
\text { SMAW }\end{array}$ & $\begin{array}{l}100 \% \mathrm{PT} \\
100 \% \mathrm{RT}\end{array}$ & CONC.\&ECC. \\
\hline CAPS & $\begin{array}{l}P 1 \\
P 4 \\
4130\end{array}$ & $\begin{array}{l}\text { SAW } \\
\text { Pulsed GMAW }\end{array}$ & $\begin{array}{l}100 \% \mathrm{PT} \\
100 \% \mathrm{RT}\end{array}$ & $\sigma 4^{\prime \prime} \mathrm{min}$. \\
\hline & $\begin{array}{l}P 1 \\
4130\end{array}$ & $\begin{array}{l}\text { SAW } \\
\text { Pulsed GMAW } \\
\text { SMAW } \\
\text { GTAW }\end{array}$ & $100 \% \mathrm{PT}$ & CHECK\&BALL \\
\hline $\begin{array}{l}\text { MANIFOLDS } \\
\text { Headers }\end{array}$ & P1 & $\begin{array}{l}\text { SAW } \\
\text { Pulsed GMAW } \\
\text { GTAW }\end{array}$ & $\begin{array}{l}100 \% \mathrm{PT} \\
100 \% \mathrm{RT} \\
\text { Part UT }\end{array}$ & RF\&RTJ \\
\hline
\end{tabular}


Figure 5 - Economical Considerations of Weld Overlayed

Fittings Versus Solid Fittings

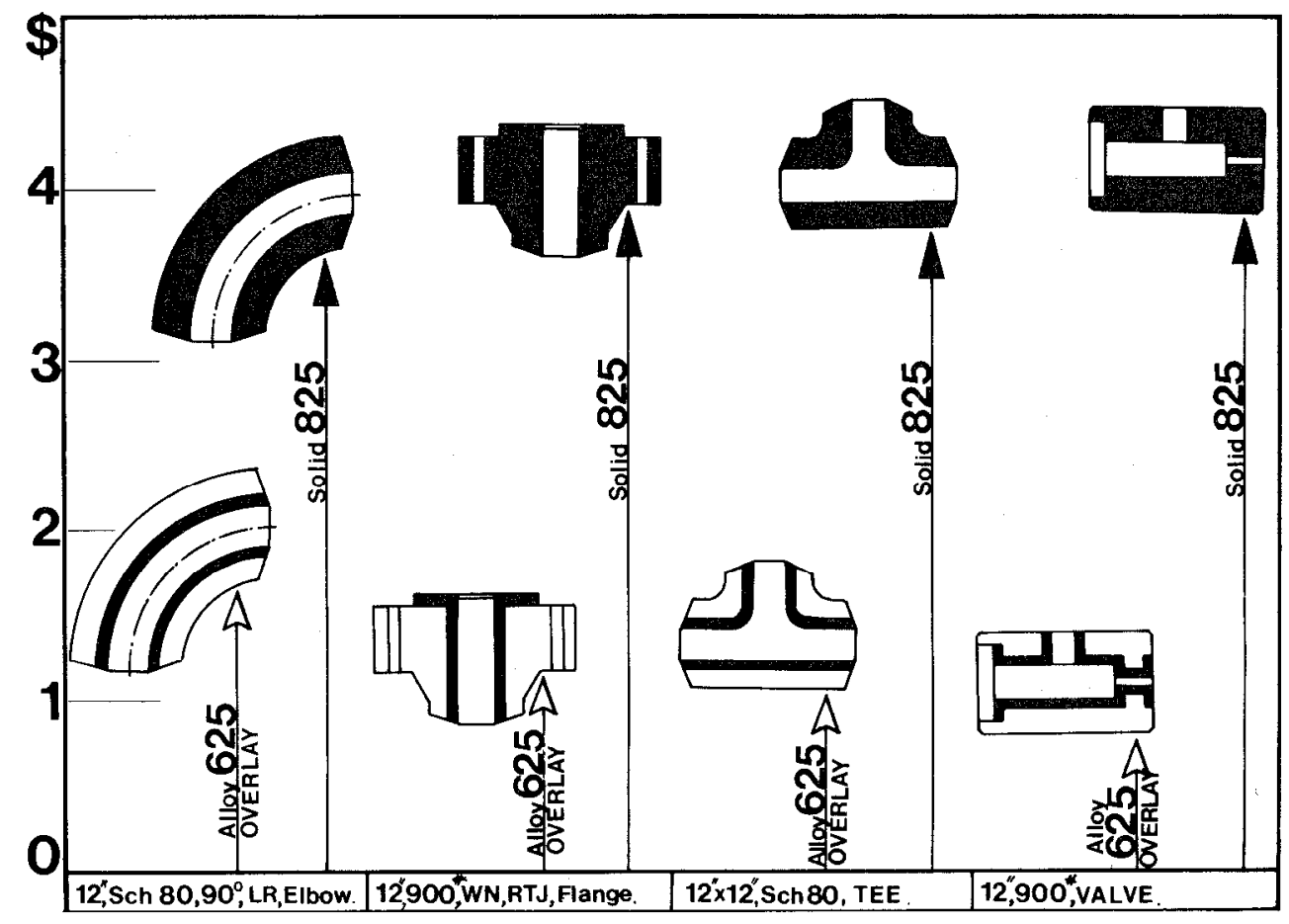

Conclusions

With the completion of the Mobil Bay Development, a very solid precedent is created: Alloy 625 weld overlayed fittings for an entire project with no exception. There are very certain conclusions that can be drawn at the time of closing this project.

1. "Shape weld Overlay" is a reality and can be achieved with specialized equipment, personnel and research and development.

2. A $100 \%$ sound weld overlay deposit can be obtained with a perfect controllable chemistry. 
3. Economical Alloy 625 weld overlayed fittings, small pipe and spools fabrication is the obvious choice for substantial savings regardless of the size of the project.

4. For both, Onshore and offshore Projects with highly corrosive environment N1loy 625 weld overlay is a proven choice that is $100 \%$ feasible from technical and economical point of view.

5. Specialized weld overlaying equipment and welding technology already tested makes it casier to continue the search for answers on similar future projects.

References

1. D, Capitanescu, , "Weld Surfacing of Small pipe Interiors", welding Journal, August $1989,29-34$.

2. R. A. Kane, S. M. Wilhelm (Cortest Laboratories Inc.), T. Yoshida, S. Matsui, T. Iwase (Kawasakj Heavy Industries), "Analysis of Bimetalic Pipe For Mobile Bay service", (Paper presented at the oTC, Houston, Texas, 7-10 May 1990), 115-128.

3. T. F. Lemke, "Heavy Section Welding of Inconel Alloy 625", (Paper presented at AWS Welding Conference, Anaheim, California, 24-26 April $1990), 1-36$.

4. N. Stephenson, "Versatility of Highly Alloyed $\mathrm{Ni-Cr-Mo} \mathrm{Welding}$ Consumables", Welding \& Metal Fabrication, August/September 1990, 376-387. 